\title{
WPS3608
}

\section{APPLICATION OF SAFEGUARDS AND ANTI-DUMPING DUTIES IN COLOMBIA}

\author{
Mauricio Reina and Sandra Zuluaga ${ }^{1}$
}

\begin{abstract}
Colombia's experience in the use of safeguards and anti-dumping duties differs from international trends. On the one hand, the number of investigations conducted is substantially lower than that recorded in most of the hemisphere's large and medium-size countries. On the other, while there is a growing international trend of more frequent use of anti-dumping as opposed to safeguards, in Colombia the safeguard process has been the more used policy instrument. Although several large and medium-size firms are familiar with the application of safeguards and anti-dumping duties, there is still a relative unfamiliarity regarding the instruments in most of the private sector. The institutional arrangements related to the investigations and the decision-making processes have proven to be stable and sound. The trade liberalization process in the country has created awareness of the importance of preserving the competitiveness of production chains to strengthen their insertion in international markets, which has restrained the authorities from restricting access to intermediate goods and raw materials. The evaluation of the Colombian experience also raises concerns about the potential discretional use of these instruments. The relatively intense use of safeguards and anti-dumping measures in some specific periods and sectors, especially in the agricultural sector, shows that the institutional framework itself is not always enough to guarantee a disciplined use of the instruments.
\end{abstract}

World Bank Policy Research Working Paper 3608, May 2005

The Policy Research Working Paper Series disseminates the findings of work in progress to encourage the exchange of ideas about development issues. An objective of the series is to get the findings out quickly, even if the presentations are less than fully polished. The papers carry the names of the authors and should be cited accordingly. The findings, interpretations, and conclusions expressed in this paper are entirely those of the authors. They do not necessarily represent the view of the World Bank, its Executive Directors, or the

\footnotetext{
${ }^{1}$ This document has taken into account some points of view of a number of Colombian Government Officials and private sector representatives. We are grateful for these opinions.
} 
countries they represent. Policy Research Working Papers are available online at http://econ.worldbank.org. 


\section{Introduction}

In some major respects, Colombia's recent experience in applying safeguards and anti-dumping duties differs from international trends. On the one hand, the number of investigations conducted is substantially lower than that recorded in most of the hemisphere's large and medium-size countries. $^{2}$ On the other, while there is a growing trend of more frequent use of anti-dumping as opposed to safeguards around the world, no such trend is observed in Colombia.

Several factors could explain the distinctive features of Colombia's experience, among them the relative ignorance of the private sector regarding the meaning and scope of the instruments, the little discretionality the government has shown in their use, and the stability and robustness of the institutions linked to the investigations and the decision-making process. Additionally, the interviews conducted in preparation of this paper indicate that there is an official awareness of the importance of preserving the competitiveness of production chains to improve the country's performance in international markets.

This document seeks to analyze the evolution in the application of safeguards and anti-dumping duties in Colombia since the beginning of the 1990's, as well as to explain its determining factors and the role these instruments have played in the country's trade policy. Section I summarizes the recent evolution of Colombia's trade policy, the framework within which the above-mentioned instruments were developed. Section II describes the evolution of the background and the current situation of legislation related to safeguards and anti-dumping duties. Section III characterizes and analyzes the various safeguards and anti-dumping investigations carried out since 1990, and discusses some case studies. Section IV deals in detail with aspects related to the political economy of the application of such instruments. Finally, Section V presents some conclusions.

\footnotetext{
2 For example, Tavares et al (2001) compares Colombia's 35 anti-dumping investigations against countries in the FTAA zone between 1987 and 2000, with 782 in the United States, 302 in Canada and 233 in Mexico.
} 


\section{THE RECENT EVOLUTION OF TRADE POLICY}

As most Latin American countries, during the second half of the last century, Colombia applied an industrialization strategy based on import substitution. While this policy promoted the diversification of the productive structure, by the end of the 1980's the protectionist strategy had become exhausted. The closed economy had fostered concentrated property structures, high prices, low product quality and few incentives for innovation. At the same time, the high cost of imports made production based on foreign raw materials more expensive, thus generating an antiexport bias in the economy.

Faced with this situation, the government implemented a trade liberalization policy that began at the end of the 1980's and was consolidated at the beginning of the 1990's, and also extended the regional integration processes. Such initiatives not only led to a reduction in the level of protection of the economy, but also created a new role for private agents in the formulation of trade policy. While protectionism had favored the development of a lobbying culture among business people to adjust policy-decisions to their interests, liberalization significantly reduced the space for that sort of lobbying.

\section{A. The Opening of Trade}

The liberalization policy comprised the elimination of quantitative restrictions to imports, the reduction of tariffs and number of tariff levels, the reduction of the number of procedures required for foreign trade, and a series of institutional reforms. ${ }^{3}$ (Hommes et al, 1994) The measures taken at the beginning of the 1990's reduced the percentage of tariff positions subject to quantitative restrictions from $73 \%$ to $1 \%$, while the economy's nominal average tariff fell from levels close to $100 \%$, to $11.1 \%$ and the effective protection was set at $26.2 \%$ (Graph I-1.)

\footnotetext{
${ }^{3}$ Before the liberalization, imports were controlled through a prior licensing arrangement and import quotas were granted taking into account criteria mainly associated with the volumes of domestic production.
} 


\section{Graph I-1}

\section{Colombia: average tariff 1986-}

2002

$\square$ Colombia $\square$ Andean average

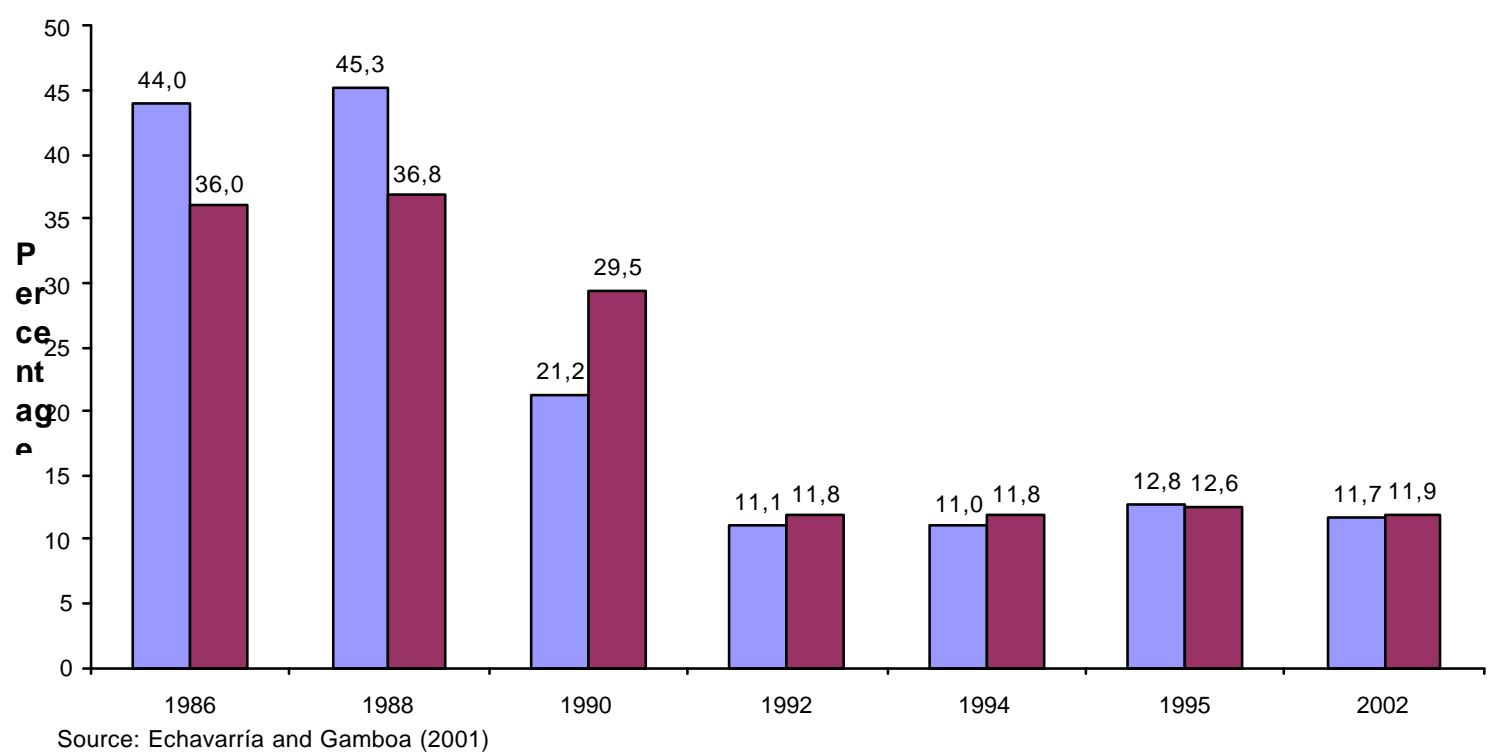

In the context of the new trade policy, a special treatment was afforded to the agricultural sector. The distortions of the international markets led to the design of a variable tariff arrangement for a sizeable number of products, i.e. price bands. With this mechanism, when international prices fall below a certain level, tariffs are automatically increased. By the same token, when international prices increase above a given level, tariffs are reduced. The price band mechanism was harmonized at the Andean level and it currently covers 13 main products and close to 150 tariff positions of derivative or substitute products. $^{4}$

Although the original objective of the Andean System of Bands was to insulate regional economies from the fluctuations of international agricultural prices, the design of the instrument had a protectionist bias that soon became apparent. In fact, the average tariff applied to the products

\footnotetext{
${ }^{4}$ The main products covered by the Andean system of price bands are meats, vegetable oils, wheat, dairy products, corn, rice, soja and sugar, as well as their derivatives and substitutes.
} 
that are part of the System reached levels close to $60 \%$ in the last few years. Although Colombian authorities have justified this situation based on the argument that this protection is a way to deal with the subsidies of developed countries, several papers have shown that the protection generated by price bands has exceeded the level of distortion generated by said subsidies. ${ }^{5}$ Thus, a good share of Colombia's agricultural sector has managed to remain outside the liberalization trends that began in 1990 .

\section{Graph I-2}

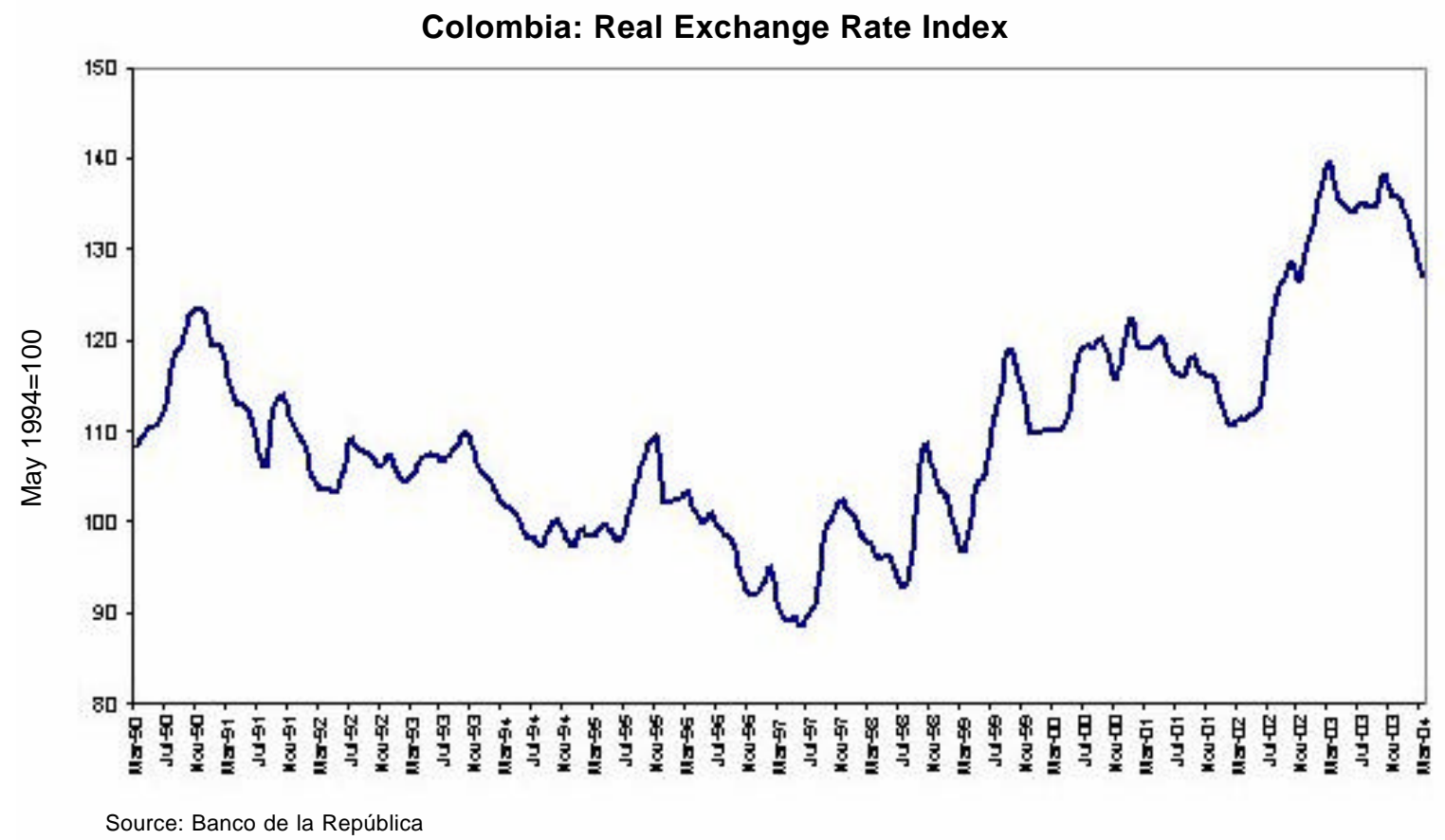

Finally, it should be mentioned that these trade reforms took place in a context of strong currency devaluations, which persisted almost uninterrupted until the end of 1997 (Graph I-2). Since the beginning of 1999 , there have been corrections to this trend and it is currently deemed that the real rate of exchange is close to its equilibrium level. However, as it will be seen later, in certain

${ }^{5}$ See Bálcazar (2003.) 
periods, the drop in the real exchange rate did not result in increased applications for anti-dumping duties and safeguards.

\section{A. Regional Negotiations}

In addition to the tariff reduction adopted between 1990 and 1991, the main factor that transformed Colombia's tariff structure was the negotiations leading to greater regional integration. In that area, the most significant processes were the strengthening of the Andean integration, the negotiation with Mexico in the framework of the Group of Three, and the signing of an agreement with Chile. Of these, the one with the greatest effective impact on Colombia's tariff structure was the strengthening of Andean integration (Reina et al. 1996).

In December 1991, the heads of the Andean countries signed the Barahona Act, which reiterated the purpose of establishing a regional free trade area and a common external tariff. These objectives were almost totally met. At the beginning of 1992, the Andean free trade zone became effective and Venezuela and Colombia established a common external tariff for most of the tariff universe. At the end of the same year, Peru suspended the liberalization program and decided to maintain significant exceptions to regional free trade. On their part, Venezuela, Colombia and Ecuador moved forward in harmonizing their tariffs in an imperfect manner, since the latter invoked its condition as a country with a lower level of relative development to maintain a tariff below that of its partners for several products.

During the mid 1990s, Colombia negotiated agreements with Chile and Mexico, with a lesser scope than the Andean integration. The agreement with Chile became effective in January 1994 and it is restricted to liberalizing trade in goods. The agreement with Mexico was negotiated in the framework of the Treaty of the Group of Three (G-3) and comprises, besides the liberalization of goods, agreements on the so-called new generation issues: services, intellectual property, government procurement, investment and dispute resolution, among others. Chart I- 1 shows the 
preferential tariff levels granted by Colombia to some countries pursuant to the regional agreements signed.

\section{Chart I-1}

\section{Preferential Tariffs granted by Colombia Liberalization Levels}

\begin{tabular}{|c|c|}
\hline COUNTRIES & COLOMBIA \\
\hline ARGENTINA & Average tariff: $10.7 \%$ \\
\hline BOLIVIA & Free trade \\
\hline BRASIL & Average tariff: $10.6 \%$ \\
\hline CANADA & $11.7 \%$ \\
\hline CHILE & $91 \%$ of tariff items excepted from duties in 1999 \\
\hline COSTA RICA & $11.7 \%$ \\
\hline ECUADOR & Free trade \\
\hline EL SALVADOR & $11.7 \%$ \\
\hline GUATEMALA & $11.7 \%$ \\
\hline HONDURAS & $11.7 \%$ \\
\hline MEXICO & Average tariff: $4.9 \%$ \\
\hline NICARAGUA & $11.7 \%$ \\
\hline PERU & List of preferences \\
\hline UNITED STATES & $11.7 \%$ \\
\hline VENEZUELA & Free trade \\
\hline Average MFN tariff level & $11.7 \%$ \\
\hline
\end{tabular}

Source: Reina and Zuluaga (2001) 
As a result of the regional integration process, the geographical distribution of Colombia's trade flows was partially modified (Annexes 1 and 2). Between 1989 and 2003, the share of the Andean Community countries increased significantly as a destination for Colombian exports. The share of other countries in the hemisphere also increased, such as those of Central America and Mexico. During the same period, imports from Andean countries and Mexico also increased their share, at the expense of those from the United States, the European Union and Japan.

\section{B. Main Institutional Reforms}

The Ministry of Foreign Trade, currently Ministry of Trade, Industry and Tourism, was created in

1991, taking over the policies that had previously been the responsibility of the Ministry of Economic Development. Its major functions include controlling the enforcement of foreign trade policies and procedures, as well as formulating and executing regional negotiation strategies.

As a result of the reforms introduced in 1991, the Colombian Institute of Foreign Trade (INCOMEX) became responsible for the prevention and investigation of unfair trade practices. The Institute's Unfair Practices Deputy Direction filled the void that existed prior to the liberalization, when there was no specific agency in charge of issues such as dumping and underinvoicing of imports. Then, in 2003 the Deputy Direction of Trade Practices of the Ministry of Trade, Industry and Tourism took on the responsibility for investigating unfair trade practices. The Deputy Direction is currently the investigating authority in cases of dumping, subsidies and safeguards, and it is charged with investigating the merits of applications, carrying out investigations and making the pertinent recommendations to decision-makers.

\section{EVOLUTION OF ANTI-DUMPING AND SAFEGUARD RULES}


The commercial opening that took place in Colombia at the beginning of the 1990s required the development of legal instruments to deal with the foreign competition that had been previously neutralized through protectionist policies.

Although Colombia had joined the GATT in 1981, the development of general safeguard rules was very limited. As opposed to this, within the framework of the Andean Group, the application of trade preferences of greater magnitude caused Andean safeguards to be used. ${ }^{6}$

The design of anti-dumping mechanisms in Colombia dates to the beginning of the trade liberalization, while the rules on safeguards were implemented in 1994. Thus, the first two antidumping rules (Decrees 1500 and 2444 of 1990) evidence the traces of a protectionist approach. Law 7 of 1991 was the basis to modify anti-dumping rules in 1993, with Decree 150 of that year, and to pass Decree 809 of 1994, which regulated safeguards for the first time in Colombia.

\section{A. Background of Anti-dumping Legislation}

Anti-dumping legislation was devised as a complement of the trade liberalization process and was regulated by Decree 1500 of 1990 . The instrument was presented to the productive sector as an option to confront unfair trade practices, with the intent of reducing the entrepreneurs' concerns regarding imports. This first norm established that imposing anti-dumping duties would respond to the public interest, with preventive or corrective purposes. ${ }^{7}$ The causes were limited to serious injury or threat of serious injury to a production existing in Colombia. Decree 1500 was rapidly replaced by Decree 2440 of 1990, which made some adjustments in the deadlines for

\footnotetext{
${ }^{6}$ The Cartagena Agreement, that gave rise to the creation of the Andean Group, contemplates four types of safeguards: sector-wide, per product, by reason of exchange rate, and another related to balance of payment crises. Between 1980 and 1990 the Andean countries invoked safeguard clauses over thirty times. Approval for the measure was granted in a little over twenty occasions, in most of which the safeguard invoked was exchange rate related.

${ }^{7}$ The concept of public interest makes reference to the obligation of taking into account, in the decision making process, all parties that may be potentially affected by the enforcement of a measure. This gives the decision maker a margin to deviate from eminently technical criteria.
} 
different stages of investigations and introduced the concept of injury by reason of massive imports.

As a result of the anti-dumping discussion in the GATT context, in 1993 a new decree was passed incorporating the refinements that had become consolidated in the multilateral scenario in terms of evidence of injury and threat of injury, as well as in the investigation procedures. This decree changed once again the setup of the Trade Practices Committee in order to adjust the new institutional arrangements for foreign trade expressed in Law 7 of 1991. In addition to the Director of the Foreign Trade Institute (Incomex), the agency responsible for the investigations, the members of the Committee included a delegate of the Senior Foreign Trade Council (Consejo Superior de Comercio Exterior), an advisor to the same council, the Vice Minister of Trade and the vice ministers of the sectors related with the investigation. ${ }^{8}$ This rule established that, before making its recommendation to the Foreign Trade Ministry, the Committee must take into advise the opinion of the Superintendent of Trade and Industry, who is responsible, among other things, for safeguarding the rights of consumers.

Decree 150 of 1993 was repealed by Decree 299 of 1995 that incorporates the progress of the Uruguay Round into Colombia's legislation. The most important changes include limiting the duration of duties to a maximum of five years, with the possibility of reviewing the duties one year after their effectiveness. The process of adjustment to the multilateral arrangements was completed with Decree 991 of 1998, the rule currently in force. For the first time in Colombia this measure introduced specific anti-dumping legislation, since the previous decrees regulated dumping and subsidies jointly.

\footnotetext{
${ }^{8}$ The Senior Foreign Trade Council is a National Government advisory organization on all aspects related to the country's foreign trade and its members are the President of the Republic, who chairs it, the ministers of the economic area, the head of the National Planning Department, the manager of the Central Bank, the Director of Customs, the advisors to the Senior Council and the President of the Foreign Trade Bank (Banco de Comercio Exterior). The last three have no voting rights.
} 


\section{B. Current Anti-dumping Regulations}

Decree 991 of 1998 regulates the application of anti-dumping duties, both for WTO member countries and non members. In the case of investigations of non-WTO members, the sectoral representation of domestic production to request an investigation requires a lower percentage. Additionally to these countries, it is possible to apply provisional duties to from the beginning of the investigation.

\section{Causes for the application of duties}

Colombia's anti-dumping legislation contemplates the three elements required by the Multilateral Trade System for the application of anti-dumping measures: (i) the existence of dumping or price differentials between the exporter's domestic market and the destination market; (ii) the threat of injury or significantly retarding the establishment of a branch of domestic production; and (iii) a causal relationship between the dumping and the above situations that may be faced by domestic production.

An analysis of the legislation in force, which is almost a copy of the multilateral disciplines, makes it possible to conclude that it preserves the margin of maneuvre that the Anti-dumping Agreement affords to investigating authorities. The Colombian Authority may select the methodology to calculate the normal value, i.e. the price that is used as a benchmark to compare with the price of exports. Similarly, the Authority may suggest the level of anti-dumping duty without any rule limiting it to the injury caused to domestic production. However, it should be noted that the regulations for the calculation of the duties do contemplate the need to consider the effect of the measures on the domestic market and on the domestic prices of the product.

Regarding the rules to determine whether there is evidence of threat of injury, injury or important retardation in a production industry, the flexibility granted by the multilateral agreements is maintained. As for the material retard in a branch of domestic production, the legislation provides 
that the factors to be reviewed include feasibility studies, loans negotiated and/or machinery purchase agreements leading to new projects or the expansion of existing plants, as well as whether the domestic market is being adequately and sufficiently supplied.

\section{Evidence to be submitted}

Colombia's legislation replicates the multilateral requirements in terms of information to initiate an investigation for dumping practices. It not only requires that the product must be identified and evidence included on the price differential must be provided, but also that information on the dumping and its effects on the Colombian market be submitted, especially with regard to price behavior. As for the requirements to open an investigation, it may be noted that besides the need to submit the respective evidence of all the required information ${ }^{9}$, it also contemplates the possibility of conducting verification visits to the applicants, a practice that is not widespread and that in some countries is limited to exporters.

\section{Procedures, instances and timeframes}

The anti-dumping process has a technical instance that takes place with the Deputy Direction of Trade Practices of the Ministry of Trade, Industry and Tourism, and an instance of a technical and political nature, which is the Committee of Trade Practices (Comité de Prácticas Comerciales). ${ }^{10}$ The Superintendent of Trade and Industry is involved in the decision on a possible price agreement, the final outcome of the investigation and the review of the anti-dumping measures established.

\footnotetext{
${ }^{9}$ Including indicators such as the actual and potential drop in sales, profits, production volume, market share and volume of imports at dumped prices.

${ }^{10}$ The members of this Committee are the Deputy Director of Trade Practices of the Ministry of Trade, a delegate of the Senior Foreign Trade Council, an advisor to said council, the Vice Minister of Trade, who chairs the Committee, and the vice ministers of the sectors connected with the investigation.
} 
The maximum time to carry out and conclude an investigation is eight months, counted from its initiation. The Deputy Direction of Trade Practices has 20 business days to evaluate the investigation application. Once the investigation has been opened, questionnaires have to be remitted to the interested parties, who have forty calendar days to answer them. The Deputy Direction of Trade Practices has 65 calendar days since the beginning of the investigation to make a preliminary decision and establish provisional duties, as may be the case. Once a preliminary determination has been adopted, the Deputy Direction of Trade Practices may obtain evidence, make verification visits and conduct hearings with the parties. In total, the Deputy Direction has three months to submit a final report to the Trade Practices Committee, as from the preliminary determination. The Committee issues an opinion that has to be circulated to the interested parties, who have 10 calendar days to make their comments. Subsequently, the Committee has 10 calendar days to review comments and produce an opinion for the Minister who, in turn, has 7 calendar days to adopt a decision.

\section{Duration of the measures}

Anti-dumping duties can be maintained for 5 years, extendable for equal successive periods, unless the exporters, foreign producers or importers of the product demonstrate there is no reason to maintain them.

\section{Background of the legislation on safeguards}

Colombia's safeguard legislation dates back to 1994, when the process of economic liberalization had already been consolidated. Said rules stemmed, on the one hand, from the need to respond to the demands of the private sector for instruments to exercise an industrial policy and on the other, to comply with the requirements derived from Colombia's membership in the World Trade Organization. The legislation, enacted by Decree 809 of 1994, applied both to tariff changes not in violation of multilateral commitments and to tariffs that exceeded the tariff levels consolidated before the WTO. 
The regulations established serious injury as a cause, defined as an important and significant deterioration in the situation of one branch of national production, and required a causal relationship between the increased imports and the injury. The application was to be filed with INCOMEX, as investigating authority, which reported to the Customs and Tariff Affairs Committee (Comité de Asuntos Aduaneros y Arancelarios) which, in turn, had to make a recommendation to the Senior Foreign Trade Council. This last instance is responsible for assessing the measure and providing an opinion to the government on its application. ${ }^{11}$

In addition to this regulation, Decree 2657 of 1994 was passed applying specifically to countries with which no trade agreements have been signed and which therefore, deviates from multilateral arrangements. It provides for the application of the measure without proof of injury or threat of injury. Subsequently, certain limits were set to the application of provisional measures and a procedure was established to impose measures to countries with which no trade agreements have been signed. ${ }^{12}$

Decree 809 of 1994 was repealed in 1998 by Decree 152, which enacted legislation for WTO member countries in accordance with multilateral arrangements, where the causes are serious injury or threat of serious injury. This is the legislation currently in force for that group of countries.

Additionally, in 1999 Decree 1407 regulated the so-called special safeguard or safeguard by reason of disruption, which applies to imports of any origin, provided that the requested tariff increase does not exceed the level consolidated by Colombia in its list of multilateral commitments

\footnotetext{
${ }^{11}$ The members of the Customs and Tariff Affairs Committee are the Vice Minister of Trade, who chairs it, the Vice Ministers of the economic area, the Deputy Chief of the National Planning Department, the Director of Customs, and the advisors to the Senior Foreign Trade Council. In 1998 it was established that to assess safeguards, the Superintendent of Trade and Industry would be invited to provide an opinion on the measure.

${ }^{12}$ Decrees 2038 and 2259 of 1996.
} 
when the investigation involves WTO member countries. This rule is less strict in terms of causes for application and is currently in force with an indefinite extension. ${ }^{13}$

\section{Current Regulations on Safeguards}

The above overview underlines the existence of several types of safeguard measures in Colombian legislation. On the one hand, there are those applicable to imports from WTO member countries, among which there are three categories: those applicable to agricultural and farm products, transition ones applicable to textiles and apparel in light of the WTO's agreement for that sector, and those applicable to the remaining products.

On the other hand, there are measures applicable to non-WTO member countries and the socalled special safeguard or safeguard by reason of disruption allowing for the increase of import duties above the Common External Tariff of the Andean Community, which applies to any country as long as the measures do not exceed the WTO consolidated tariff levels. Additionally, there are safeguards applicable to products which have been the object of tariff liberalization in the framework of Regional Integration Agreements, such as the Andean safeguards, the safeguard in the Agreement of the Group of Three, and the safeguard of the Agreement between Colombia and Chile.

This paper will focus on the analysis of the safeguard for WTO member countries (Decree 152 of 1998) and the special safeguard (Decree 1407 of 1999). The former may be characterized as a safeguard by reason of injury, and the latter as a safeguard by reason of disruption.

\section{WTO Safeguard}

\section{a) Causes for measures}

\footnotetext{
${ }^{13}$ Decree 2681 of 2001.
} 
The WTO safeguard (Decree 152 of 1998) requires imports of the affected product to have increased, whether in absolute terms or in comparison with the domestic production of the good, and in conditions that cause or threaten to cause a serious injury to a branch of domestic production. Additionally, it also established that the investigation should prove causal relationship between the injury or the threat of injury and the increase in imports.

\section{b) Evidence to be submitted}

The regulations require submitting financial and accounting information, signed by a public accountant, on the industry corresponding to the product to be investigated. It also requires submitting information on the objectives that the applicant firm will attain within the so-called adjustment program, which refers to the adoption of modernization programs to increase competitiveness and adapt to the new competitive conditions.

\section{c) Procedures, instances and terms}

An investigation related to a safeguard by reason of injury lasts approximately 127 days in the technical instance, during which the Custom and Tariff Affairs Committee and the Senior Foreign Trade Council make their decisions. The former has 15 business days to review the technical

report and make a recommendation to the latter. If the recommendation is positive, the Ministry of Trade is asked to conduct consultations. Finally, the Senior Foreign Trade Council adopts the measure. According to the regulations, if the recommendation from the Customs and Tariff Affairs Committee is negative, the Senior Foreign Trade Council may deviate from it and request that consultations be held.

\section{d) Term of the Measures}

Safeguard measures have a maximum term of four years, extendable for another four. 


\section{Special Safeguard}

The decree regulating the so-called special safeguard defines it as a "special procedure to impose safeguard measures." This mechanism is not strictly a safeguard according to WTO parameters. The measure that is applied is a tariff increase above the common external tariff agreed with the Andean countries, but for WTO member countries it may not exceed the tariff level consolidated before this Organization. Based on that characteristic, this instrument has not been notified to the WTO as a safeguard.

The special safeguard has several differences with the general legislation established in 1998. Firstly, the cause to invoke this rule is that an important proportion of a domestic production branch has suffered or could suffer a disruption by reason of an increase in imports or imports occurring in unfair conditions, such as low prices or large quantities. ${ }^{14}$ Secondly, the rule does not require an adjustment program to be submitted by the applicant firm.

Thirdly, the rule shortens the period of investigation, since it establishes that the Deputy Direction of Trade Practices will have 20 business days to produce recommendations to the Custom and Tariff Affairs Committee, as opposed to 25 days pursuant to Decree 152 of 1998. Besides, all necessary visits and evidence must be completed within this 20 day term. The Customs and Tariff Affairs Committee has 5 business days to make its technical report and submit it to the Senior Foreign Trade Council, as compared to 15 days under Decree 152 of 1998. Finally, the safeguard measures by reason of disruption are limited to the imposition of a duty and can only remain in force for two years, non-extendable.

In summary, Colombia's legislation on dumping and safeguards follows the guidelines developed by the WTO at the multilateral level. However, there are two aspects in these regulations that stand out because of their analytical interest. The first relates to the fact that there are two different

\footnotetext{
${ }^{14}$ Decree 1407 of 1999.
} 
decision-making instances for the application of duties and for the adoption of safeguard measures. The general modification of the tariff that a safeguard implies must have the approval of the instance studying tariff policy (Customs and Tariff Affairs Committee) and the President of the Republic. In contrast, a tariff modification resulting from a process of defense against unfair competition is the responsibility of the Minister of Trade.

The second factor relates to the so-called "special safeguard", which isn't strictly a safeguard but a mechanism that makes it possible to increase tariffs above the Andean commitments, without infringing multilateral rules, and gives the government greater flexibility in the decision-making process.

\section{ANALYSIS OF DUMPING AND SAFEGUARD INVESTIGATIONS IN COLOMBIA. ${ }^{15}$}

The first dumping and safeguards investigations in Colombia date back to the end of the 1990's and mid 1994, in coincidence with the implementation of each of the laws on these matters.

Between 1990 and 2004, 37 dumping investigations have taken place in Colombia (an average of 2.6 cases per year), while there were 34 safeguards-related investigations between 1994 and 2004 (3.4 cases per year). The greater dynamism of safeguard investigations is due to the number of cases in the Andean Community. During this period, 12 investigations were conducted in the Andean zone, while the investigations carried out within the framework of the WTO and for the so-called special safeguard amount to 11 and 10 cases, respectively (Chart III.1.) If the Andean safeguards are excluded, the yearly average would drop to 2.1 investigations per year. ${ }^{16}$

\footnotetext{
${ }^{15}$ This section draws on the information included in Annexes 3 and 4.

${ }^{16}$ As seen in the second section of this paper, the special safeguard is not strictly a safeguard but rather an arrangement that allows for tariff measures to be levied up to the level consolidated in the WTO, and is higher than the tariffs applied pursuant to the Andean Common External Tariff (AEC.)
} 
Independently from whether the Andean safeguards are included in the calculation or not, Colombia's experience differs from the international trend regarding the adoption of this type of measures vis-a-vis anti-dumping duties. According to Finger (2002), between 1983 and 1993, an annual average of 3 safeguard measures was reported to the GATT, in accordance with Article XIX of the Agreement, while the yearly average of dumping cases was 164 . While the worldwide statistic is one safeguard case for every 55 cases of dumping per year, for Colombia the figure is almost 1 to $1 .^{17}$

\section{Chart III.1}

\section{INVESTIGATIONS CONDUCTED}

1990-2004

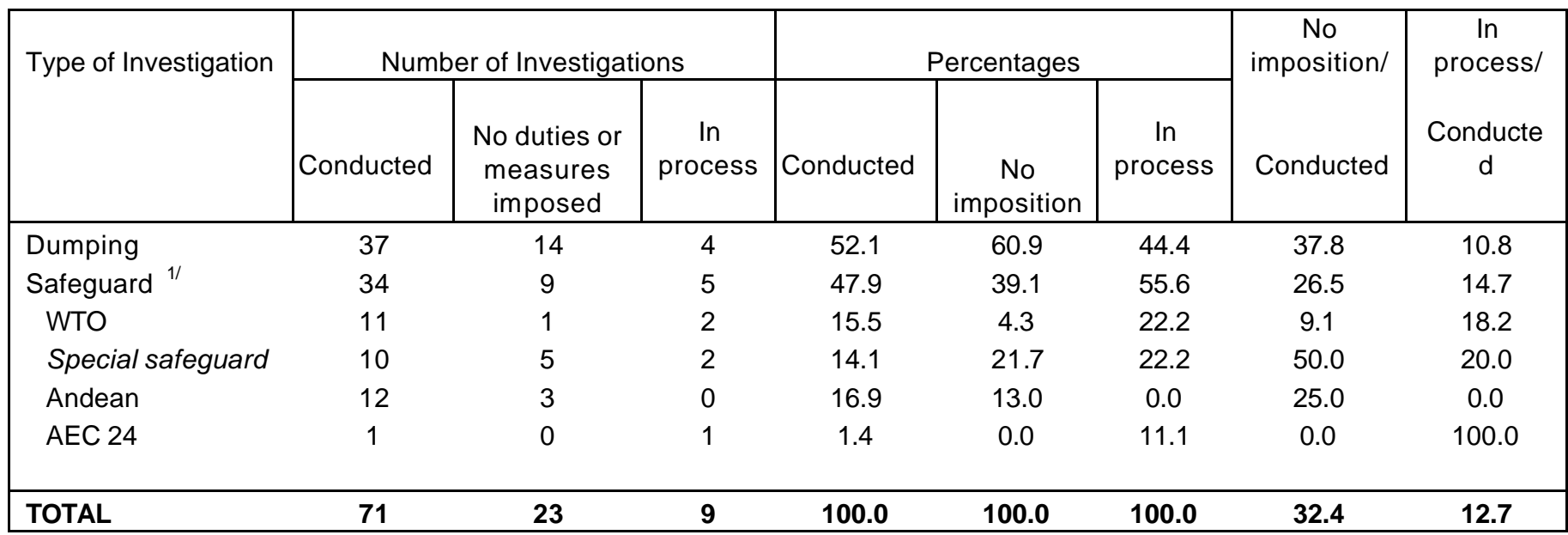

${ }^{1 /}$ The information on safeguards is broken down in accordance with the existing legislation, Decree 152/98 for WTO member countries; Decree 1407/99 for all the so-called special safeguard countries; Andean rules; ACE 24, which is the Agreement between Colombia and Chile within the framework of ALADI, using ALADI's Resolution No. 70.

Source: Calculated by the authors based on Ministry of Trade data.

\section{A. Evolution of investigations 1990-2004}

Between 1990 and 2004 there have been a total of 71 dumping and safeguard related investigations in Colombia. Of these, 37 are dumping investigations and 34 are safeguard

\footnotetext{
${ }^{17}$ Finger, J.M. (2002), "Safeguards: Making sense of GATT/WTO provisions allowing for import restrictions" in Development, Trade and the WTO: a Handbook, Bernard Hoekman, Aaditya Mattoo and Philip English eds., World Bank.
} 
investigations. Of the latter, $17 \%$ have been Andean safeguards, $14 \%$ special safeguards and 15\% WTO safeguards (Chart III.1.)

In 23 cases out of the total investigations conducted in the above period, no duties or measures were levied. Breaking down the figures, it is found that $61 \%$ of the investigations where no duties were imposed correspond to dumping cases, as compared to 39\% for safeguard cases. Among the various classes of safeguards, the special safeguard accounts for the highest number of cases where no measures were applied, followed by the Andean safeguard. As of the first semester of 2004, 9 of the 71 investigations conducted were in process (4 cases of dumping and 5 of safeguards), of which 2 were submitted under the WTO rules and 2 under the so-called special safeguard.

The highest number of anti-dumping applications was submitted in 1998, while 2001 stands out as the year when more safeguard applications were filed. It may be noted that there does not seem to exist a relationship between the use of the instruments and the evolution of the exchange rate, since the highest number of applications was submitted during the period of greatest devaluation. What does seem evident is that the introduction of a more flexible instrument such as the special safeguard, generated a demand for this type of commercial defenses (Graph III.1.)

\section{Graph III.1}




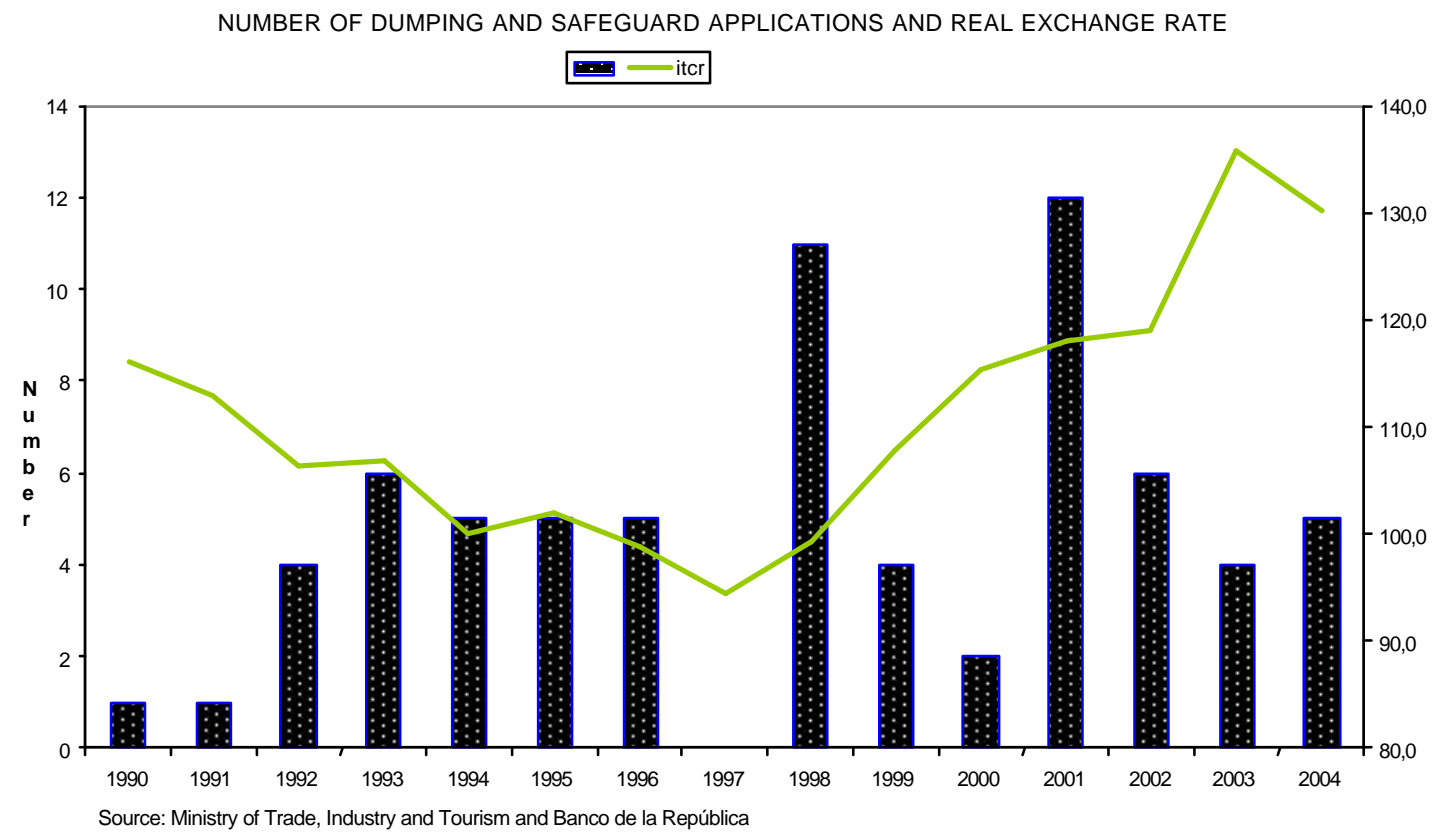

Finally, two aspects related to safeguard investigations may be highlighted. On the one hand, the figures evidence a greater relative use of the so-called special safeguard as compared to the WTO safeguard. Although the number of WTO safeguard investigations is almost equal to those of the special safeguard, the period during which the two instruments have been in force indicates a greater dynamism in the application of the latter. In the ten years of existence of the WTO safeguard, there has been, on average, one investigation per year, while the average number of investigations under the special safeguard has been 2 per year between 1999 and 2004. The preference for this last type of instrument could be the result of less stringent requirements to prove the disruption and of shorter periods of investigation and decision-making than those contemplated in the WTO safeguard.

Summarizing, between 1990 and 2004 Colombia has made a relatively equal use of the antidumping and safeguard arrangements. To a great extent this trend is the result of the recurrent use of the Andean safeguard, although if it is excluded from the statistics, an important number of 
safeguard investigations still remain. ${ }^{18}$ It may be noted that the proportion of investigations not resulting in the levying of duties or measures has been higher in the case of dumping investigations. Additionally, with the adoption of the special safeguard in 1999, the conditions were created for an increase in the number of applications linked to this type of measures.

\section{E. Sectors applying for investigation}

Out of the total investigations conducted between 1990 and 2004, 17\% corresponded to agricultural products, understood as the summation of agriculture and agricultural industry products, and $83 \%$ to industrial products (Chart III.2). The agricultural sector has made greater use of the safeguard mechanism as compared to anti-dumping measures. Of the total investigations conducted for agricultural products, $25 \%$ were for dumping and $75 \%$ for safeguards, and of the later percentage, three fifths corresponded to Andean measures.

Of the dumping investigations, $92 \%$ focused on industrial products and only $8 \%$ corresponded to agricultural ones. In the case of safeguards, $26.5 \%$ corresponded to agricultural products and the remaining $73.5 \%$ to industrial goods. The case of the Andean safeguard stands out, to the extent that $58 \%$ of the investigations conducted refer to agricultural products. The investigations under the special safeguard only relate to industrial products.

\section{Chart III.2}

INVESTIGATIONS BY SECTORS (1990-2004)

\begin{tabular}{|c|c|c|c|c|c|c|}
\hline \multirow{3}{*}{ Mechanism } & \multicolumn{4}{|c|}{ Number of Investigations } & \multirow{2}{*}{\multicolumn{2}{|c|}{ No imposition/ Conducted }} \\
\hline & \multicolumn{2}{|c|}{ Conducted } & \multicolumn{2}{|c|}{ No duty or measures imposed } & & \\
\hline & Agricultural & Industrial & Agricultural & Industrial & Agricultural & Industrial \\
\hline Dumping & 3 & 34 & 3 & 11 & 100.0 & 32.4 \\
\hline Safeguard & 9 & 25 & 0 & 9 & 0.0 & 36.0 \\
\hline WTO & 1 & 10 & 0 & 1 & 0.0 & 10.0 \\
\hline Special & 0 & 10 & 0 & 5 & & 50.0 \\
\hline
\end{tabular}

\footnotetext{
${ }^{18}$ The application of the Andean safeguard contributes to making the number of safeguard cases not much lower than those of dumping. However, if the Andean investigations are substracted, the percentage of safeguard cases is still $37 \%$ of the total, as compared to $63 \%$ linked to dumping.
} 


\begin{tabular}{|l|cccccc|} 
Andean & 7 & 5 & 0 & 3 & & 60.0 \\
AEC 24 & 1 & 0 & 0 & 0 & 25.0 & 33.9 \\
\hline TOTAL & 12 & 59 & 3 & 20 & 2.0 \\
\hline
\end{tabular}

\begin{tabular}{|l|cc|c|c|}
\hline \multirow{2}{*}{ Mechanism } & \multicolumn{4}{|c|}{ Percentage breakdown of total investigations } \\
\cline { 2 - 5 } & \multicolumn{3}{|c|}{ Conducted } & \multicolumn{2}{c|}{ No duty or measures imposed } \\
\cline { 2 - 5 } & Agricultural & Industrial & Agricultural & Industrial \\
\hline Dumping & 25.0 & 57.6 & 100.0 & 55.0 \\
Safeguard & 75.0 & 42.4 & 0.0 & 45.0 \\
WTO & 8.3 & 16.9 & 0.0 & 5.0 \\
Special & 0.0 & 16.9 & 0.0 & 25.0 \\
Andean & 58.3 & 8.5 & 0.0 & 15.0 \\
AEC 24 & 8.3 & 0.0 & 0.0 & 0.0 \\
\hline TOTAL & 100.0 & 100.0 & 100.0 & 100.0 \\
\hline
\end{tabular}

\begin{tabular}{|l|cc|c|c|}
\hline \multirow{3}{*}{ Mechanism } & \multicolumn{4}{|c|}{ Percentage breakdown per mechanism } \\
\cline { 2 - 5 } & \multicolumn{3}{|c|}{ Conducted } & \multicolumn{2}{c|}{ No duty or measures imposed } \\
\cline { 2 - 5 } & Agricultural & Industrial & \multicolumn{1}{|c|}{ Agricultural } & Industrial \\
\hline Dumping & 8.1 & 91.9 & 21.4 & 78.6 \\
Safeguard & 26.5 & 73.5 & 0.0 & 100.0 \\
WTO & 9.1 & 90.9 & 0.0 & 100.0 \\
Special & 0.0 & 100.0 & 0.0 & 100.0 \\
Andean & 58.3 & 41.7 & 0.0 & 100.0 \\
AEC 24 & 100.0 & 0.0 & & \\
\hline TOTAL & 16.9 & 83.1 & 13.0 & 87.0 \\
\hline
\end{tabular}

Source: Calculations by the authors based on data from the Ministry of Trade.

Another interesting result is that all the investigations for dumping of agricultural products have ended with no duties being imposed, while in the case of industrial products, duties were denied in $32 \%$ of the cases. In the case of safeguards, it may be noted that all the investigations conducted for agricultural products have ended with the levying of measures, while $36 \%$ of the investigations for industrial products have resulted in no measures being imposed.

A more detailed breakdown of the sectors that have requested the application of anti-dumping duties shows that chemicals, iron and steel products and petrochemicals represent almost $70 \%$ of the investigations (Chart III.3). ${ }^{19}$

19 In most sectors, the investigations have concentrated on a few products. The cases of dumping in the chemical sector focus on orthophosphoric acid, ethyl acetate and fertilizers; in the petrochemical sector, polypropylene and suspension type polyvinyl chloride. The agricultural products are corn byproducts, poultry and rice. In textiles the investigated products are denim, polyester fiber and texturized yarns. In iron 
Chart III.3

DUMPING INVESTIGATIONS BY SECTORS

1990-2004

\begin{tabular}{|l|ccc|c|c|}
\hline \multirow{2}{*}{ Sectors } & \multicolumn{2}{c|}{ Number of Investigations } & \multicolumn{2}{c|}{ Percentage breakdown } & Wo. Duties/ \\
\cline { 2 - 6 } & Conducted & Wo. Duties & Conducted & Wo. Duties & Conducted \\
\hline Agricultural products & 3 & 3 & 8.1 & 21.4 & 100.0 \\
Chemicals & 10 & 2 & 27.0 & 14.3 & 20.0 \\
Petrochemicals & 7 & 1 & 18.9 & 7.1 & 14.3 \\
Tires & 2 & 2 & 5.4 & 14.3 & 100.0 \\
Textiles & 3 & 3 & 8.1 & 21.4 & 100.0 \\
Tableware and crockery or china & 2 & 0 & 5.4 & 0.0 & 0.0 \\
Iron \& Steel Products & 9 & 2 & 24.3 & 14.3 & 22.2 \\
Stationary Batteries & 1 & 1 & 2.7 & 7.1 & 100.0 \\
\hline \multicolumn{1}{|c}{ TOTAL } & $\mathbf{3 7}$ & $\mathbf{1 4}$ & $\mathbf{1 0 0 . 0}$ & $\mathbf{1 0 0 . 0}$ & $\mathbf{3 7 . 8}$ \\
\hline
\end{tabular}

Source: Calculations by the authors based on data from the Ministry of Trade.

As for the safeguards, the sectoral breakdown is relatively different according to the type of instrument (Chart III.4). Most of the investigations under the WTO safeguard were made for textiles and apparel, and home appliances. Besides these two sectors, special safeguard investigations focus on chemicals and petrochemicals. In the case of the Andean safeguard, almost $60 \%$ of the cases are agricultural and focus on two products: rice and vegetable oils.

Summarizing, most of the dumping and safeguards investigations have involved industrial products. Additionally, the investigations on agricultural products have mainly concentrated on safeguards and in those few cases in which the application of anti-dumping duties were requested for this sector, they were denied. Finally, textiles, apparel, iron and steel products, and chemicals and petrochemicals are the sectors requesting more investigations, which is consistent with international patterns. In effect, data for dumping investigations in the western hemisphere shows that these tend to concentrate on chemicals, plastics, paper, textiles and basic metals. ${ }^{20}$

\section{Chart III.4 SAFEGUARD INVESTIGATIONS BY SECTORS}

and steel the products are steel bars, chrome plated sheets, iron or steel wire rods, billets, tin sheet and hotrolled steel.

${ }^{20}$ Tavares et al (2001) Antidumping in the Americas. 
1994-2004

\begin{tabular}{|c|c|c|c|c|c|}
\hline \multirow[t]{2}{*}{ Type of safeguard } & \multicolumn{2}{|c|}{ Number of investigations } & \multicolumn{2}{|c|}{ Percentage breakdown } & \multirow{2}{*}{$\begin{array}{l}\text { Wo. Measures/ } \\
\text { Conducted }\end{array}$} \\
\hline & Conducted & Wo. Measures & Conducted & Wo. Measures & \\
\hline \multicolumn{6}{|l|}{ WTO SAFEGUARDS } \\
\hline Rice & 1 & 0 & 9,1 & 0,0 & 0,0 \\
\hline Shoes & 1 & 0 & 9,1 & 0,0 & 0,0 \\
\hline Textiles and apparel & 6 & 0 & 54,5 & 0,0 & 0,0 \\
\hline Home appliances & 2 & 0 & 18,2 & 0,0 & 0,0 \\
\hline Taxis & 1 & 1 & 9,1 & 100,0 & 100,0 \\
\hline TOTAL & 11 & 1 & 100,0 & $100, C$ & 9,1 \\
\hline \multicolumn{6}{|l|}{ SPECIAL SAFEGUARD } \\
\hline Chemicals and petrochemicals & 3 & 1 & 30,0 & 20,0 & 33,3 \\
\hline Textiles and apparel & 3 & 2 & 30,0 & 40,0 & 66,7 \\
\hline Chains & 1 & 0 & 10,0 & 0,0 & 0,0 \\
\hline Home appliances & 3 & 2 & 30,0 & 40,0 & 66,7 \\
\hline TOTAL & 10 & 5 & 100,0 & $100, C$ & 50,0 \\
\hline \multicolumn{6}{|l|}{ ANDEAN COMMUNITY } \\
\hline Agricultural products & 7 & 0 & 58,3 & 0,0 & 0,0 \\
\hline Extra-neutral alcohol & 1 & 1 & 8,3 & 33,3 & 100,0 \\
\hline Polypropylene bags & 2 & 1 & 16,7 & 33,3 & 50,0 \\
\hline Triplex and particle boards & 1 & 0 & 8,3 & 0,0 & 0,0 \\
\hline Iron \& Steel Products & 1 & 1 & 8,3 & 33,3 & 100,0 \\
\hline TOTAL & 12 & 3 & 100,0 & $100, C$ & 25,0 \\
\hline \multicolumn{6}{|l|}{ AEC 24 ALADI } \\
\hline Agricultural products & 1 & 0 & & & \\
\hline TOTAL & 34 & 9 & & & 26,5 \\
\hline
\end{tabular}

Source: Calculations by the authors based on data from the Ministry of Trade.

Note: agricultural products appearing in the Andean safeguard are rice and refined vegetable oils.

\section{F. TWO CASE STUDIES}

An analysis of the previous sections suggests that it is interesting to look into two sectors more deeply. The first one is the agricultural sector, from which rice was selected for this paper because of the persistence in time of the measures to protect it against imports. This case is illustrative of the difficulty to manage the liberalization process when political considerations seem to prevail over technical ones.

The second one is the textile-apparel sector, which reveals the problems that are created in a production chain when inputs become more expensive due to the application of duties or 
safeguard measures. In this case, the government's decisions privileged the defense of the competitiveness of the productive chain.

\section{Rice}

Rice stands out as one of the agricultural products with the highest number of investigation applications, both for dumping and safeguards. However, it should be noted that the commercial defenses imposed during the period under analysis were almost exclusively concentrated in the Andean market and suspended the benefits derived from the Andean free trade area.

\section{a) Sector evolution}

Rice represents approximately $12 \%$ of Colombia's cultivated area, it is the third most important crop in terms of extension, after coffee and corn, and represents $6 \%$ of the agricultural production. ${ }^{21}$ This product is covered by the price band system, whereby the average ad valorem tariff between 1995 and 2003 was around 40\%.

According to 1999 data, the country has around 34,000 rice production units and a milling industry that employs approximately 5,000 people. The milling industry has an advanced level of technological development when compared to countries such as the United States, Brazil and Venezuela. In 2001, Colombia was ranked $23^{\text {rd }}$ in world rice production and third in the FTAA after the United States and Brazil. Yields per hectare are above the international average, with 4.9 tons as compared to a world average of 3.9 .

The trade balance of rice had a deficit throughout almost all the 1990's. During the decade, the imports of rice have mainly originated from three countries: Ecuador, the United States and Venezuela. Ecuador and Venezuela's share of imports are $43 \%$ and $21 \%$, respectively, while the United States and the Asian countries have shares of $21 \%$ and $13 \%$.

${ }^{21}$ See Ministry of Agriculture (2002), Características y estructura de la cadena de arroz en Colombia. Observatorio de competitividad agrocadenas, Colombia. 


\section{b) Use of Trade Restrictions}

Rice stands out, together with refined oils, for concentrating most of the investigation applications involving agricultural products, both on grounds of dumping and safeguards. In the meetings held for this project with officials and former officials of the Ministry of Trade, there was a consensus on the strong political pressure that historically characterized the investigations of this product. It is important to note that, in the case of the applications for safeguards filed within the framework of the Andean Community, in two occasions the Government acted on its own initiative.

The quantity of investigations and measures applied to the product during the period under analysis is surprising. One of the three investigations that were conducted since 1990 on grounds of dumping of agricultural products was done in 1994 concerning rice from Vietnam, and the application of duties was denied. Almost simultaneously there was a safeguard application motivated by the imports of the product from Vietnam, which ended with the levying of a tarifftype measure that was to be reviewed at mid 1995.

Later there were four investigations relating to safeguards for the product within the framework of the Andean Community, as a result of which imports were suspended for the period comprised between January 1996 and May 1998, through extensions of the measure and the application of contingent measures during 2002 and 2003. It should be noted that the Andean safeguard does not establish a maximum period of application of a measure nor a limit to the extensions. Given the composition of the countries that supply rice to Colombia, the regulation of Andean imports affects a high percentage of the imports.

As could be expected, this measure has generated an ongoing issue in the Andean Community, (especially with Ecuador), taking into account that Colombia is the main producer of rice in the Andean region, followed by Peru and Ecuador. As from 2004, the Ministry of Agriculture implemented the so-called Mechanism of Administration of Contingent Duties (MAC, for the 
Spanish language acronym) for some agricultural products -rice among them — and it is therefore expected that the recurrent application of safeguards for this product in the Andean market will be abandoned. $^{22}$

\section{Textiles and Apparel}

The textiles-apparel sector is analytically interesting to the extent its representatives - together with those of the agricultural sector- have been noted for being most critical of the trade liberalization policy. This characteristic could help explain why, when analyzing trade defense instruments, this sector turns out to be among those that has applied for more measures and where the government has conducted several investigations on its own initiative. However, the government denied the imposition of duties and the adoption of safeguard measures when pertinent.

\section{a) Sector Evolution}

The textiles sector represents close to $6 \%$ of the industrial production and the apparel sector approximately 3\%, and they both constitute one of the sectors with the highest average tariffs in Colombia. While the average of the MFN average tariff is close to $11 \%$, the average duty for this sector is $18 \%$. The textiles sector shows a high concentration in a small number of firms, while the apparel sector is particularly atomized.

The economic opening of the early 1990s had an important impact on these two sectors, especially on textiles, due to the growing penetration of imports in a context in which not all of the links in the production chain had a good competitive position. Colombia's textiles and apparel industry had been characterized by a low penetration of imports in the period prior to the trade liberalization. By 1990, apparel's penetration of imports was 3.2\% while that of textiles was $4.4 \%$, with some exceptions in certain sub-sectors of manufactured textile products other than

\footnotetext{
${ }^{22}$ The MAC works as an imports management instrument subject to the absorption of the national harvest.
} 
apparel. By the end of the 1990s, this indicator had increased to almost $30 \%$ in textiles and close to $10 \%$ in apparel.

At the time of the opening, the cotton textile industry faced high labor costs and heavy indebtedness, as a result of an investment program leading to modernization and the reduction of labor costs. However, the companies in the sub-sector of woven products presented more advantageous competitive conditions in terms of low labor costs, low debt burden and vertical disintegration, and were able to respond more rapidly to the changes in the domestic and external demand. In the synthetic fibers sector, trade liberalization caused the closure of most of the existing companies, which were multinational and adopted strategies of regional relocation. Only one company (ENKA) survived the opening, in part due to the fact that it continued enjoying the tariff advantages derived from the Andean market.

In the case of apparel, it is difficult to identify a distinctive behavior pattern, given the heterogeneity of the sector. However, it may be noted that during the 1990s apparel firms that competed in the high volume and low price market were particularly hit, while those dedicated to maquila processes or those that manufacture low to medium volumes at medium to high prices both for the domestic and international markets succeeded in surviving.

At the beginning of the 1990s, the whole production chain suffered the impact of a strong unfair competition generated by smuggling, due to the circumstantial exports of Asian products at very low prices, which affected all the countries in the region. This situation led to considerable financial losses and in some cases resulted in the closing down or bankruptcy of firms, especially in the textiles sector. 
The difficult circumstances faced by the sector during the 1990s did not lead to the adoption of a particular commercial and industrial policy by the authorities. However, the sector was included within the competitiveness policy applied by the government between 1994 and $1998 .^{23}$

In 1997 the government signed competitiveness agreements pursuant said policy with the textiles and apparel sector. In the commercial field, such agreements resulted in temporary tariff reductions for the import of capital goods and raw materials, a stronger enforcement of smuggling controls, and the modification of the legislation regarding safeguards and anti-dumping, to expedite investigations and introduce flexibility in the application criteria. However, as seen in the section on the evolution of the regulations of these instruments, the Government did not deviate from the multilateral arrangements in this regard. Only in the case of the so-called special safeguard it may have been responsive to private sector's demands as reflected in the competitiveness agreement, but it should be noted that this instrument is not a safeguard in the strict sense of the word. Besides, almost all the applications made by the sector for the imposition of this instrument were denied.

\section{b) The Use of Trade Restrictions}

Since 1990, there have been three dumping investigations and nine investigations to apply safeguard measures to products of the textiles-apparel sector in Colombia. This sector is not among those that has requested more anti-dumping measures, but -together with the agricultural sector - it is included in the group that has requested more safeguard measures.

In no case did the applications for dumping result in the imposition of duties, while the adoption of measures was denied in only two of the nine safeguard investigations. The two denied safeguard measures were submitted through the special safeguard mechanism, while the six applications

\footnotetext{
${ }^{23}$ The competitiveness policy was based on the joint work of the Government and the private sector to improve some cross-cutting issues that affect the performance of the economic sectors. These factors include regulations, transport, infrastructure, human resourc es qualifications and raw materials import costs.
} 
filed for the WTO safeguard, including the transition facility of the Textiles and Apparel Agreement, ended with the imposition of measures.

As mentioned above, there are two elements of interest for this analysis. On the one hand, the fact that two of the safeguard applications denied in 2001, for polyester fibers and texturized yarns, included an express recommendation to the Foreign Trade Ministry to begin a dumping investigation on its own initiative, which ended without duties being levied. On the other, this is the sector in which there was an objection to the safeguard measures applied within the WTO framework, in particular by Asian countries such as Thailand and Taiwan, but the objection did not go beyond a regular proceeding, at the end of which the measures had expired.

The conclusions on the effect of the measures are not obvious. Textiles and apparel imports grew at a declining rate until the middle of the 1990s, and at a lower average level during the second half of the decade. However, this is difficult to explain based exclusively on the use of commercial defense mechanisms since as from 1996 the economy suffered a sharp drop in growth. Finally, the amounts of both textile and apparel imports have not dropped to pre-liberalization levels (Graph III.2). 


\section{Graph III.2}

TEXTILE AND APPAREL IMPORTS

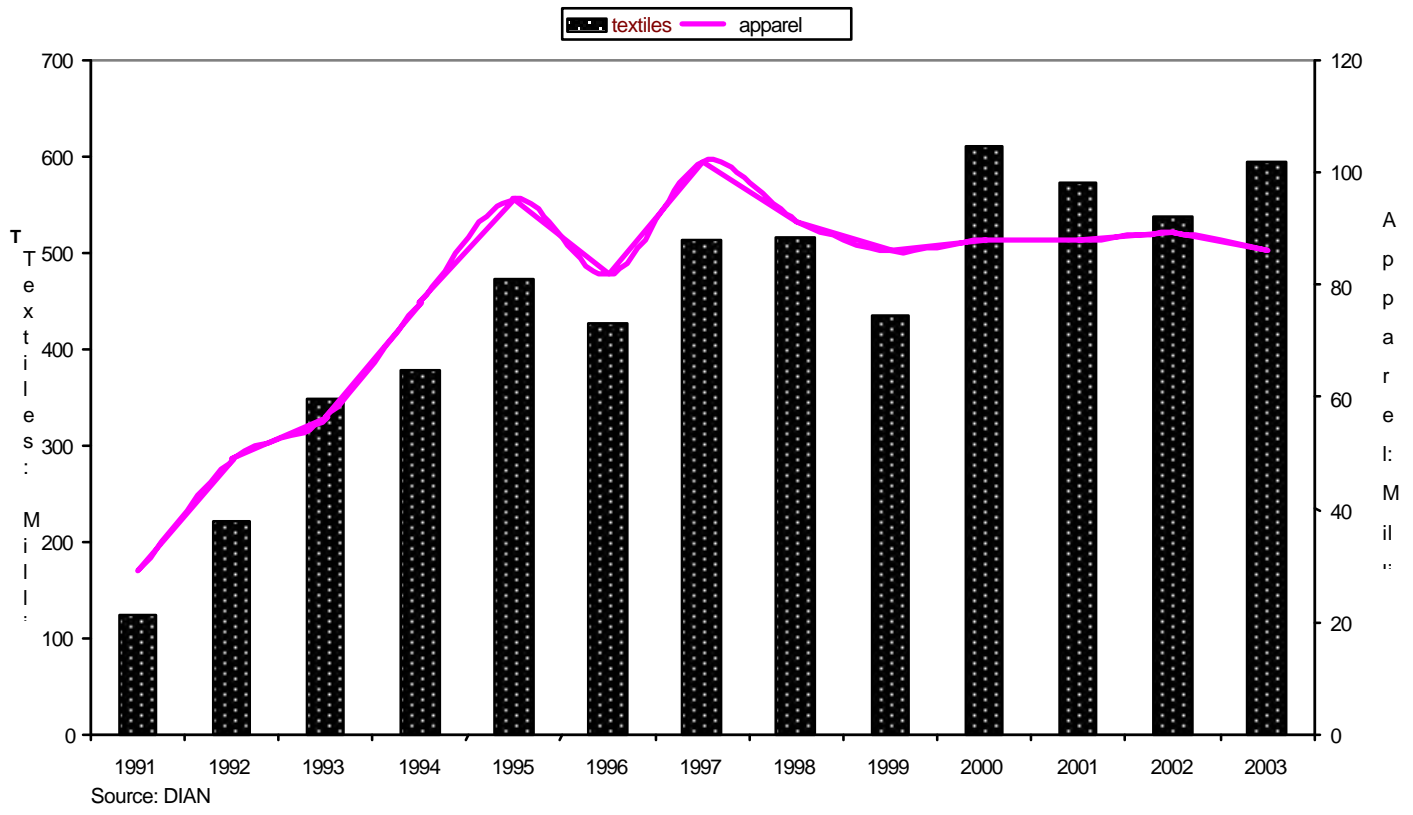

A review of the investigations carried out evidences the government's concern to act on behalf of the whole production chain. The case of synthetic yarns and fibers is illustrative in their condition as raw materials. Although for the decision-makers it was clear that the survival of the production lines of a firm with a long history in the country was at stake, no safeguard measures were applied, there was an unsuccessful dumping investigation and the government simply promoted an agreement of the production chain to purchase polyester granules, another product of the same company.

\section{POLITICAL ECONOMY OF THE USE OF SAFEGUARDS AND ANTI- DUMPING MEASURES IN COLOMBIA}

A review of the investigations conducted in the last few years by Colombia's authorities to impose safeguard and anti-dumping measures reveals that there has not been a bias in favor of using one of the two instruments. Between 1990 and so far in 2004, 37 investigations into alleged cases of 
dumping and 34 to assess the imposition of safeguards were initiated. ${ }^{24}$ Duties were imposed in $59 \%$ of the investigations for safeguards, while $51 \%$ of the cases of alleged dumping had a similar result.

The pattern of use of safeguards and anti-dumping measures seems to respond to several factors. On the one hand, the design of the various instruments and the requirements for their imposition makes some easier to apply than others. On the other, although the institutional structure related with the decision-making process seems to have maintained a political space for the emergence of more or less protectionist inclinations of the government of the day, such discretionality seems not to have been used excessively. Finally, the profile of those who apply for the investigations (in terms of size, economic sector, etc.), also seems to play a role in the relative use of the instruments.

\section{A. The Role of the Instruments}

As already mentioned, the evolution of Colombia's anti-dumping legislation has followed two routes. On one hand, each new legal instrument in this regard has sought to better adapt to the multilateral regulations provided by the WTO. On the other, through time there is a clear tendency to making procedures more expeditious, always within the multilateral guidelines.

The case of safeguards legislation has a different feature, to the extent that in the last few years the authorities have not only passed instruments in accordance with the evolution of the multilateral arrangements, which offer little margin for discretionality, but have moreover designed and implemented a more lax mechanism, so much so that, as mentioned, it is not a safeguard in the strict sense of the word but has an equivalent relief effect for the private sector within the margin of maneuver granted by the multilateral framework for tariff policy. A review of the circumstances

\footnotetext{
${ }^{24}$ As already explained and analyzed in further detail below, the cases of safeguards include those of the socalled "special safeguard", which in a strict sense does not constitute a safeguard from the WTO's perspective, but has played an important role in granting protection to various sectors.
} 
under which these instruments were designed and the way they have been employed leads us to assert that the use of the so-called special safeguard is more accessible to the private sector, and offers greater discretionality to the authorities than anti-dumping instruments.

The first safeguard instrument, enacted by Decree 809 of 1994, was the result of an initiative by the Government of the day designed to offer a lifesaver to sectors that at the time were under hardship due to the greater competition generated by the commercial opening. However, this initiative had more of a political than practical meaning, since the conditions imposed for application prevented its massive use. The instrument was modified to adjust it to WTO rules by Decree 152 of 1998, which remains in force.

While the use of the safeguard applicable to WTO member countries has been partially limited due to its strict requirements, there are three types of instruments offering greater flexibility. The first of these is a safeguard applicable to countries which are not members of the WTO, where the requirements for investigation are less strict and authorities have greater discretionality. ${ }^{25}$

The second is the procedure denominated special safeguard. Although this instrument does not allow for the increase of tariffs above the levels consolidated before the WTO, it has been very useful for authorities since it allows them to increase tariff levels above the Andean Common External Tariff, thus becoming an important relief measure for the private sector.

The interviews conducted for this paper show that the enactment of the special safeguard sought to offer a more flexible mechanism to respond to protection requests by the private sector. A review of the requirements of the instrument seems to confirm it, since it introduces the concept of disruption, defined as an increase in imports or the existence of imports in unfair conditions such as low prices or important quantities, a concept less demanding that that of injury.

\footnotetext{
${ }^{25}$ This safeguard was regulated by Decree 2657 of 1994 and later by Decree 1407 of 1999.
} 
The requirements to demonstrate a disruption are much more vague and lax than those corresponding to the demonstration of injury. The relative use of the special safeguard seems to show that the private sector perceives it as a "user-friendly" instrument; since 1999 there have been 10 special safeguards investigations, a figure similar to the 11 investigations that were conducted since 1994 for WTO consistent safeguards.

The third instrument that has made it possible to channel the demand of the private sector with greater flexibility than the WTO-consistent safeguard, is the safeguard applicable among Andean countries. This safeguard is an important relief mechanism for the private sector, to the extent that it makes it possible to suspend the benefits of the free trade area of the Andean region, which is the source of a significant portion of the imports of some products. ${ }^{26}$

The Andean safeguard has three conditions that facilitate its use. On the one hand, its application does not demand compensation to the countries affected by the measure. On the other, it makes use of the concept of disruption which, as already noted, is more lax than that of injury. Finally, the Andean regulations contemplate the levying of provisional duties while the Andean Community Secretariat makes a determination on each case. This circumstance guarantees a minimum of four months of protection, even in those cases in which the measure is considered to be unwarranted. The fact that 12 out of the 34 investigations that were initiated based on safeguard applications have corresponded to the Andean regulations, is an indication of the relative importance of the instrument to respond to the demands of the private sector.

\section{B. The Role of Institutions}

It is possible to identify three instances in the investigation and decision-making processes regarding safeguard and anti-dumping measures applications. The first instance is responsible for carrying out the investigation processes, and it has always reported hierarchically to the Ministry of Foreign Trade.

\footnotetext{
${ }^{26}$ See Annex 2 on the geographical source of Colombia's imports.
} 
Once the investigations have been conducted, the Deputy Direction of Trade Practices formulates a recommendation and submits the case to the second instance, at the vice-ministerial level. In the case of investigations into alleged dumping, this second instance is the Unfair Practices Committee, while in the case of investigations linked to safeguards, it is the Customs and Tariff Affairs Committee. Both Committees are chaired by the Foreign Trade Vice-Minister and, with slight variations, have the vice-ministers of the economic areas as members.

The instance making the final determination in the case of dumping investigations is the Minister of Foreign Trade. In general terms, there have been no cases of a Minister making a decision that opposes the recommendations of the Unfair Practices Committee, which underlines the importance of rigorous investigations and subsequent discussions among of the vice-ministers of the economic area. The instance making the final decision in applications linked to safeguard investigations is the Senior Foreign Trade Council, that has the Ministers of the economic areas as members and is chaired by the President of the Republic, which may deviate from the recommendations of the Customs and Tariff Affairs Committee. It is worthwhile noting that the Ministry of Agriculture usually undertakes the defense of the applications filed by this sector, which is not the case with the investigations requested by the industrial sector. With a few exceptions, this Council has operated with formal rigor and usually its decisions have had solid foundations.

The interviews conducted for this paper revealed that the work of the officials responsible for the investigations complies with the regulatory requirements and is not usually interfered by political pressures from senior government levels, which does not mean that officials are fully protected from that sort of pressures. At the same time, the discussions of the vice-ministers usually balance technical and political criteria. Although such behavior is the general rule, there have been some minor exceptions that coincide with periods in which the government of the day had suffered a political setback, and sought to remedy it by granting preferential treatment to some representatives of the private sector. It may be noted that these temporary exceptions have not 
eroded the institutionality of the processes. In an interview with a Government official, an interesting hypothesis emerged in this sense. In his judgement, the fact that the majority of the applications for investigation has involved raw materials has made it very difficult to take measures for the benefit of a specific group, since the dynamics of liberalization has made evident the need to preserve the competitiveness of production chains in order to improve their insertion in international markets.

The analysis of the institutional operation in the cases of dumping and safeguards indicates that, with the above-mentioned exceptions, the officials responsible for the investigation usually work in a serious and independent manner, and their recommendations are assessed by the vice-ministerial instance that brings together both technical and political criteria. The general opinion of those interviewed is that technical rigor has prevailed in that instance and the recommendations are generally adopted by the Minister or Senior Foreign Trade Council, as may be the case. According to this diagnosis, although authorities do have a margin for political considerations to prevail over technical criteria, this has not been the dominant behavior in Colombia.

There is, however, one instance in which the inclination of the government or the minister of the day toward greater or lesser protection has become effective. It lies in the ability to modify the instruments and their procedures within the boundaries permitted by multilateral regulations. The issuance of the so-called special safeguard in 1999 is a case in point, to the extent that it opened up the possibility of a more discretional and expeditious protection in response to requests from the private sector. In other words, in some cases, by adjusting the rules, the authorities have sought to attain the flexibility and discretionality that are not afforded by the investigation and decision-making processes.

Finally, it cannot be asserted that the relatively little use of the anti-dumping and safeguard instruments in Colombia stems from a lack of resources. Although the Deputy Direction of Trade Practices has a staff of 10, including administrative officials, those interviewed estimate that the staffing is qualified and sufficient to process the applications that are filed. In the opinion of the 
current Deputy Director of Trade Practices, having more staff would make it possible to investigate cases more in depth and would reduce the workload per official, but would in no case determine the adoption of a greater number of measures or reduce the time. Additionally, although the budget is limited, resources have always been found to make on-site verifications and collect first-hand information.

\section{The Role of the Applicants and the Affected Counterparts}

The sectors having requested more dumping investigations are, in order, chemicals, iron and steel and oil by-products. On the other hand, the sectors that have requested more investigations for the application of safeguards have been textiles, apparel, agricultural products (through the Andean safeguard), chemicals and petrochemicals. It may be noted that most of these sectors coincide with the majority of the dumping and safeguard investigations in the world.

According to the interviews conducted for this document, the bulk of the private sector is ignorant on the use and meaning of the anti-dumping instruments and safeguards. The exception is usually found in large companies or in those that have traditionally been involved in foreign trade. In fact, the interviews show that, with a few exceptions, the companies that usually request an investigation for the imposition of antidumping measures and safeguards are those that have enough resources to pay a law firm. Similarly, investigation applications usually come from relatively concentrated sectors, in which it is easier for the interested parties to reach an agreement to demonstrate that an important proportion of a branch of domestic production has been affected.

While hiring a law firm is not a requirement to file an application for investigation, most of the applicant firms usually prefer it. The competent authorities offer the firms induction mechanisms to apply for an investigation directly, an assistance that has been used in some instances. However, in most cases, the applying companies do not have sufficient staff to take care of the case directly, or they believe that law firms have an expertise that is worthwhile using. Additionally, it is clear that by hiring a law firm, interested parties not only acquire the technical expertise to file the application 
but also the potential of lobbying for the corresponding follow-up, sometimes at the most senior level.

The preference for hiring law firms reinforces the trend for most applications to come from the largest companies. It is worthwhile noting that, although rates vary, the cost of hiring a law firm to apply for an investigation may amount to 50,000-75,000 dollars for the whole process. Importantly, the authorities or former officials consulted for this paper indicated that there is no bias in favor of applications filed by law firms.

Several respondents pointed out that the applicants for investigations do not have a bias in favor of safeguards or antidumping mechanisms, and that they choose to request one or the other depending on the case they believe can be established. However, experts who have followed closely several cases pointed out that firms tend to perceive that it is more feasible to build a solid case by way of the safeguards, since the information required is of a domestic nature and more readily obtainable than that about international prices and/or costs required for a dumping case. This perception is probably reinforced by the greater flexibility of instruments such as the special safeguard or the Andean safeguard mentioned above.

An analysis of the role played by the affected parties in an anti-dumping or safeguards investigation shows a mixed result. On the one hand, the technicians responsible for the investigations always comply with the requirement of consultation with the parties affected in the process. The respondents coincided in pointing out, however, that the role of the counterparts is limited because they have a shorter time to prepare their arguments than the one that was available to the applicants, since the later are already preparing their allegations prior to the submittal of the application.

The relative lack of knowledge on the instruments and their operation also limits the potential reaction of the counterparts, since in many cases they become intimidated when they learn that the authorities are conducting an investigation, and prefer not to engage in the debate. In the case of 
dumping investigations, this situation usually results in the party that is the importer of the goods choosing to change the supplying country to avoid the problems they believe may be derived from the investigation.

The stakeholder that is more absent in dumping and safeguard investigations is the consumer. Colombia does not have strong consumer associations to make their positions felt in the large national economic debates, let alone a specialized investigation. The only exception in this sense is the sporadic presence of the Superintendent of Trade and Industry at the vice-ministerial instance that analyzes the recommendations of the Deputy Direction of Trade Practices. This Superintendency is responsible for conducting the investigations related to anti-competitive practices and usually has consumer interests very much in mind. However, the Superintendency does not always attend the vice-ministerial meetings and when it does, it only has the right to speak but no vote.

\section{CONCLUSIONS}

Colombia's experience with the use of antidumping duties and safeguards shows that the government has not resorted to this option to satisfy the demands of the economic agents looking

for greater protection, and that the number of applications that are filed is low when compared to international standards.

This trend can be explained by the private sector's relative ignorance regarding the instruments, and by the stability and soundness demonstrated by the institutional arrangements connected with the investigations and the decision-making process, even if they are not independent agencies within the government's structure.

The interviews and the cases analyzed in this document show that the dynamics of the trade liberalization process in the country created awareness on the importance of preserving the competitiveness of production chains to improve their insertion in the international markets. This 
fact has placed the government at a complex cross-roads at the time of restricting access of cheap raw materials, which helps explain the stability and prudence in the institutions associated with the process of commercial defense. However, the agricultural sector seems to lie beyond this logic and to the extent allowed by the instruments, the domestic market has often been closed, at least for Andean competition. The case of rice is illustrative in this regard. 


\section{REFERENCES}

Edwards (1995). Crisis and Reform in Latin America: From Despair to Hope, Oxford University Press, World Bank, Washington, D.C.

Echavarría, J.J. and C.Gamboa (2001). "Colombia y Venezuela: reformas de política comercial y ajustes institucionales después de la Ronda de Uruguay", Coyuntura Económica, vol. XXI, no.3-4, Sep-Dec. 2001.

Echavarría, J, Zuleta, L.A. and Zuluaga S. (2000) Estudio sobre el impacto sectorial de la integración andina: el caso del sector textil y confección - Inter-American Development Bank INTAL.

Finger, J. M. (2002) "Safeguards: Making sense of GATT/WTO provisions allowing for import restrictions" in Development, Trade and the WTO: a Handbook, Bernard Hoekman, Aaditya Mattoo and Philip English eds., World Bank.

Hommes et al. (1994), Una apertura hacia el futuro, Ministry of Finance and Public Credit and National Planning Department.

Ministerio de Agricultura (2002), Características y estructura de la cadena de arroz en Colombia. Observatorio de competitividad agrocadenas, Colombia.

Reina M. Zuluaga S. and Gamboa C. (1996), El Grupo de bs Tres y el Grupo Andino, in Américas, integración económica en perspectiva, National Planning Department and InterAmerican Development Bank, 1996.

Reina M. and Zuluaga S. (2001), Lineamientos para una estrategia de negociación de Colombia en Acceso a Mercados en el ALCA, Mimeo. 
Tavares et. al. (2001) Antidumping in the Americas, OAS Trade Unit Studies, March 2001. 


\begin{tabular}{|c|c|c|c|c|c|c|}
\hline \multicolumn{7}{|c|}{ ANNEX 1- Colombia: Total export destinations in 1989 and 2003} \\
\hline \multicolumn{3}{|c|}{1989} & \multicolumn{3}{|c|}{2003} & \multirow{2}{*}{$\begin{array}{c}\text { Avg. annua } \\
\text { Variation }\end{array}$} \\
\hline Country/Zone & Share & US \$ Millions & Country/Zone & Share & US \$ Millions & \\
\hline CAN (4) & 5.4 & 309.3 & CAN (2) & 14.5 & $1,905.2$ & 13.87 \\
\hline Canada (9) & 1.5 & 86.7 & Canada & 1.3 & 176.5 & 5.21 \\
\hline Chile (7) & 2.3 & 131.7 & Chile (9) & 1.4 & 188.2 & 2.58 \\
\hline Other Alca & 8.8 & 505.3 & Other Alca & 9.2 & $1,201.7$ & 6.38 \\
\hline Other E. Occ. & 0.7 & 40.4 & Other E. Occ. & 1.1 & 141.5 & 9.36 \\
\hline United States & 40.8 & $2,343.2$ & United States & 44.3 & $5,797.5$ & 6.68 \\
\hline Japan & 4.4 & 250.2 & Japan & 1.5 & 201.5 & -1.53 \\
\hline MCCA (11) & 0.9 & 52.2 & MCCA (6) & 2.8 & 363.9 & 14.87 \\
\hline Mercosur (10) & 1.0 & 59.1 & Mercosur (12) & 0.9 & 117.5 & 5.03 \\
\hline Mexico (13) & 0.4 & 25.1 & Mexico (7) & 2.7 & 358.2 & 20.89 \\
\hline PECE (6) & 2.9 & 165.6 & PECE & 0.5 & 68.5 & -6.11 \\
\hline Others & 1.7 & 97.2 & Others & 5.4 & 704.9 & 15.20 \\
\hline $\mathrm{EU}$ & 29.2 & $1,676.5$ & $\mathrm{EU}$ & 14.3 & $1,875.8$ & 0.81 \\
\hline TOTAL & 100.0 & $5,742.7$ & TOTAL & 100.0 & $13,100.8$ & 6.07 \\
\hline \multicolumn{7}{|c|}{ Source: Fedesarrollo figures with DANE data. } \\
\hline & & & & & & . \\
\hline
\end{tabular}




\begin{tabular}{|l|l|l|l|l|l|l|}
\hline \multicolumn{7}{|c|}{ ANNEX 2- Colombia: Source of total imports in 1989 and 2003 } \\
\hline Country/ Zone & Share & US \$ Millions & Country/ Zone & Share & US \$ Millions & Variation \\
\hline CAN (6) & 7.2 & 360.1 & CAN (4) & 11.1 & $1,446.8$ & 10.4 \\
\hline Canada (7) & 4.0 & 202.0 & Canada (8) & 2.2 & 287.7 & 2.6 \\
\hline Chile (9) & 1.8 & 91.3 & Chile (9) & 2.1 & 275.6 & 8.2 \\
\hline United States (1) & 36.3 & $1,824.5$ & United States (1) & 29.6 & $3,853.9$ & 5.5 \\
\hline Japan (4) & 8.6 & 434.0 & Japan (7) & 4.6 & 604.5 & 2.4 \\
\hline MERCOSUR (5) & 8.4 & 421.6 & MERCOSUR (5) & 7.8 & $1,020.8$ & 6.5 \\
\hline Mexico (8) & 2.5 & 123.4 & Mexico (6) & 5.4 & 708.2 & 13.3 \\
\hline Others & 9.7 & 488.2 & Others (2) & 21.5 & $2,801.4$ & 13.3 \\
\hline EU (2) & 21.5 & $1,080.3$ & EU (3) & 15.5 & $2,023.5$ & 4.6 \\
\hline TOTAL & 100.0 & $5,025.4$ & TOTAL & 100.0 & $13,022.4$ & 7.0 \\
\hline Source: Fedesarrollo figures with DANE data. & & & & \\
\hline Notes: Between Brackets is the place the country or zone occupied in the ranking of the respective year. \\
\hline
\end{tabular}

